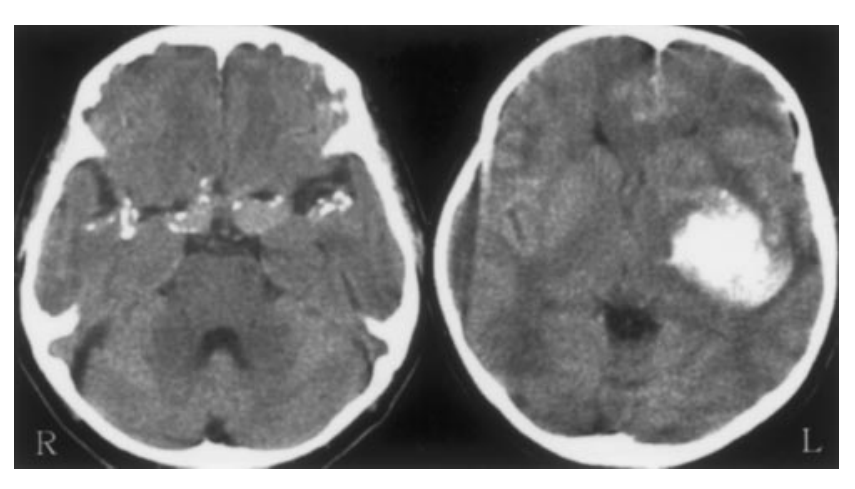

Figure 1. In the basal cistern, CT scans show homogeneous isodensity elongated masses, surrounded by flecks of high density. Large hematoma is seen in the left putamen.

\section{Hemorrhage with dolichoectatic middle cerebral arteries}

Takashi Tokunaga, MD, and Toru Yamamoto, MD, Osaka, Japan

A 58-year-old woman was admitted to our hospital with lethargy, right hemiplegia, and right homonymous hemianopia. An emergency CT showed a large hemorrhage in the left putamen and distorted bilateral middle cerebral arteries with numerous

Address correspondence and reprint requests to Dr. T. Tokunaga, Department of Neurology, Osaka Saiseikai Nakatsu Hospital, 2-10-39 Shibata Kitaku, Osaka 530-0012, Japan; e-mail: neuro@nakatsu.saiseikai.or.jp

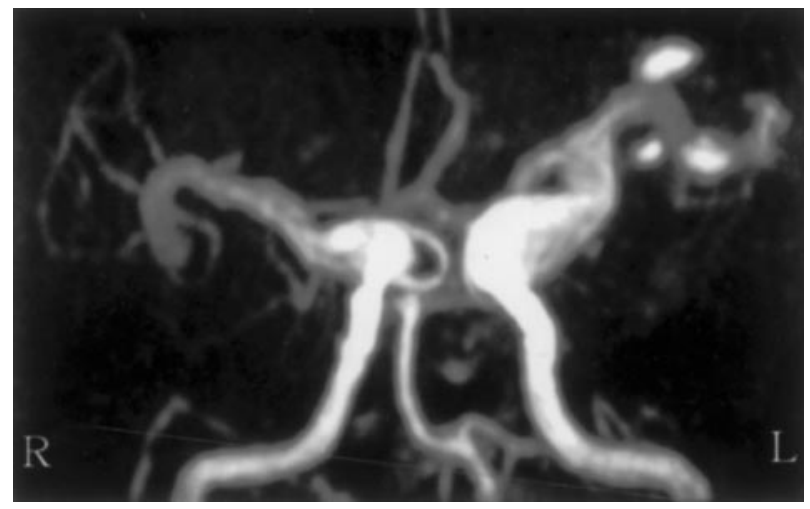

Figure 2. On MR angiography, bilateral middle cerebral arteries are tortuous, elongated, and dilated.

calcified deposits in their walls (figure 1), which was confirmed by MR angiography and conventional angiogram (figure 2). Laboratory investigation disclosed no significant risk factors except for hypertension. Over several months, she recovered considerably.

Dolichoectatic intracranial artery is known to cause ischemia ${ }^{1}$ and rarely subarachnoid hemorrhage from the affected arterial wall. ${ }^{2}$ Notably, there has been no report of intracerebral hemorrhage associated with this condition.

1. Ince B, Petty GW, Brown RD, Chu CP, Sicks JD, Whisnant JP. Dolichoectasia of the intracranial arteries in patients with first ischemic stroke: a population-based study. Neurology 1998;50:1694-1698.

2. Goldstein SJ, Tibbs PA. Recurrent subarachnoid hemorrhage complicating cerebral arterial ectasia. J Neurosurg 1981;55:139-142. 


\title{
Neurology
}

\author{
Hemorrhage with dolichoectatic middle cerebral arteries \\ Takashi Tokunaga and Toru Yamamoto \\ Neurology 2003;61;E4 \\ DOI 10.1212/01.WNL.0000064161.61921.CA
}

This information is current as of July 21, 2003

\section{Updated Information \& Services}

References

Subspecialty Collections

Permissions \& Licensing

Reprints including high resolution figures, can be found at: http://n.neurology.org/content/61/2/E4.full

This article cites 2 articles, 1 of which you can access for free at: http://n.neurology.org/content/61/2/E4.full\#ref-list-1

This article, along with others on similar topics, appears in the following collection(s):

\section{All Cerebrovascular disease/Stroke}

http://n.neurology.org/cgi/collection/all_cerebrovascular_disease_strok e

\section{All Imaging}

http://n.neurology.org/cgi/collection/all_imaging

CT

http://n.neurology.org/cgi/collection/ct

Intracerebral hemorrhage

http://n.neurology.org/cgi/collection/intracerebral_hemorrhage

MRI

http://n.neurology.org/cgi/collection/mri

Information about reproducing this article in parts (figures,tables) or in its entirety can be found online at:

http://www.neurology.org/about/about_the_journal\#permissions

Information about ordering reprints can be found online:

http://n.neurology.org/subscribers/advertise

Neurology ${ }^{\circledR}$ is the official journal of the American Academy of Neurology. Published continuously since 1951, it is now a weekly with 48 issues per year. Copyright . All rights reserved. Print ISSN: 0028-3878. Online ISSN: 1526-632X.

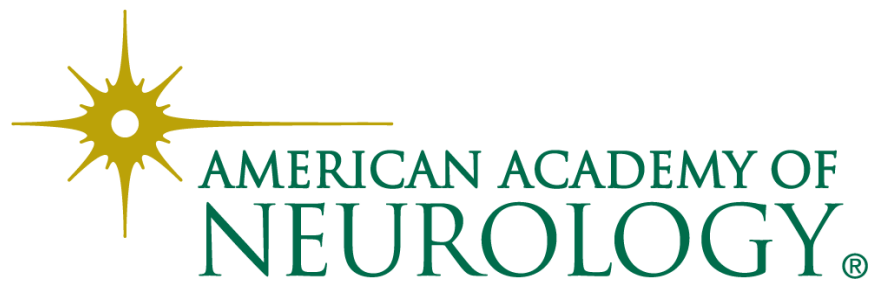

